\title{
Atypically located cluster headache
}

\author{
Atipik yerleşimli küme baş ağrısı
}

\section{Taner ÖZBENLi,' ${ }^{1}$ Çetin Kürşad AKPINAR²}

\section{Dear Editor,}

Cluster headache $(\mathrm{CH})$ is characterized by attacks of strictly unilateral, severe pain with orbital, supraorbital, or temporal location. They are accompanied by ipsilateral cranial autonomic features. Typical characteristics are short duration; pain occurring on one side of head, including eye area; and extreme intensity. ${ }^{[1]}$ Pathophysiology of $\mathrm{CH}$ is not fully understood. ${ }^{[2]}$ The pain almost always manifests itself in the same location during each attack. In this report, an atypically located $\mathrm{CH}$ is presented.

A 45-year-old man presented with a 1-year complaint of right-sided headache. He described episodes of excruciating, burning pain in right parietal region. His pain was daily or recurring every second day. A burning sensation lasting 2-3 minutes would occur, immediately followed by headache of extreme intensity lasting 15-20 minutes. Pain was accompanied by tearing of right eye. Between attacks he was headache free. There was no circadian rhythmicity to the attacks. Restlessness was present during the attacks. Patient has been smoking cigarettes for the last 30 years. His neurological examination was normal, with exception of $20 \%$ muscle loss in the right arm. Magnetic resonance imaging (MRI) of the brain, brainneck computerized tomography (CT) angiographies, brain magnetic resonance venography (MRV) and cerebral digital subtraction angiography (DSA) were found to be normal. Cervical and brain diffusion MRI were found to be normal. His electrodiagnostic evaluation was normal.
Subcutaneous sumatriptan was not given to the patient because of his right arm weakness. During the attack, there was no response to $100 \%$ oxygen inhalation (10 L/min). Intravenous methylprednisolone, $1000 \mathrm{mg}$ for 5 days, was ineffective for excruciating, burning pain attacks. Dosage of $620 \mathrm{mg}$ verapamil decreased intensity and frequency of headaches. Occipital nerve block was applied once a week for 4 weeks. Attacks occurred once or twice per week after occipital nerve block. Lithium (900 mg/day) was added to verapamil and headache attacks stopped. Right arm paresis had improved on $13^{\text {th }}$ hospital day. Headache was experienced over a wide area, including upper and lower teeth, forehead, jaw, cheek, neck, nose, ear, shoulder, vertex, occiput and parietal lobe. Reported parietal pain location is very rare in $\mathrm{CH}(1 \%){ }^{[3]}$

Atypical presentation of $\mathrm{CH}$ usually means atypical attack duration and frequency, abnormal findings on neurological examination, and atypical symptoms. ${ }^{[4]}$ The term generally used for atypical $\mathrm{CH}$ is secondary $\mathrm{CH}$ or cluster-like headache. In $\mathrm{CH}$ patients, atypical localization of pain has been seen in ear, nose, shoulder or parietal region, but pain was always also located in periorbital region. Solely extra-orbital or extratemporal pain in $\mathrm{CH}$ patients is rare..$^{[5]}$

\section{References}

1. Headache Classification Committee of the International Headache Society (IHS). The International Classification of

'Department of Neurology, Ondokuz Mayıs University Faculty of Medicine, Samsun, Turkey

${ }^{2}$ Department of Neurology, Vezirköpru State Hospital, Samsun, Turkey

Submitted (Başvuru tarihi) 10.04.2015 Accepted after revision (Düzeltme sonrası kabul tarihi) 23.06.2015

İletişim (Correspondence): Dr. Çetin Kürşad Akpınar. Vezirköprü Devlet Hastanesi, Nöroloji Kliniği, Samsun, Turkey

Tel: +90 - $362-6471824$ e-posta (e-mail):dr_ckakpinar@hotmail.com

๑) 2016 Türk Algoloji Derneği 
Headache Disorders, 3rd edition (beta version). Cephalalgia 2013;33(9):629-808.

2. Sjöstrand C, Russell MB, Ekbom K, Hillert J, Waldenlind $E$. Familial cluster headache. Is atypical cluster headache in family members part of the clinical spectrum? Cephalalgia 2005;25(11):1068-77.

3. Bahra A, May A, Goadsby PJ. Cluster headache: a prospective clinical study with diagnostic implications. Neurology 2002;58(3):354-61.
4. Rozen TD. Atypical presentations of cluster headache. Cephalalgia 2002;22(9):725-9.

5. Favier I, Haan J, van Duinen SG, Ferrari MD. Typical cluster headache caused by granulomatous pituitary involvement. Cephalalgia 2007;27(2):173-6.

- This case was presented at the $6^{\text {th }}$ World Congress of the World Institute of Pain, February 4-6, 2012. 